Int. J. Dev. Biol. 54: 561-565 (2010)

doi: $10.1387 / \mathrm{ijdb} .092908 \mathrm{ds}$

\title{
Michael Akam and the rise of evolutionary developmental biology
}

\author{
DAVID L. STERN*,1 and RACHEL E. DAWES-HOANG ${ }^{2}$ \\ ${ }^{1}$ Howard Hughes Medical Institute and Department of Ecology and Evolutionary Biology, Princeton \\ University, Princeton, NJ and ${ }^{2}$ Department of Biology, Haverford College, Haverford, PA, USA
}

\begin{abstract}
Michael Akam has been awarded the 2007 Kowalevsky medal for his many research accomplishments in the area of evolutionary developmental biology. We highlight three tributaries of Michael's contribution to evolutionary developmental biology. First, he has made major contributions to our understanding of development of the fruit fly, Drosophila melanogaster. Second, he has maintained a consistent focus on several key problems in evolutionary developmental biology, including the evolving role of Hox genes in arthropods and, more recently, the evolution of segmentation mechanisms. Third, Michael has written a series of influential reviews that have integrated progress in developmental biology into an evolutionary perspective. Michael has also made a large impact on the field through his effective mentorship style, his selfless promotion of younger colleagues, and his leadership of the University Museum of Zoology at Cambridge and the European community of evolutionary developmental biologists.
\end{abstract}

KEY WORDS: Michael Akam, Kowalevsky Medal, Evolutionary Developmental Biology

\section{The 2007 Kowalevsky Medal Prize Winner}

Professor Michael Akam, one of the founders of modern evolutionary developmental biology, has won the 2007 Alexander Kowalevsky Medal (Fig. 1). This prize recognizes outstanding contributions to the field of evolutionary developmental biology. The Kowalevsky medal is awarded in memory of the $19^{\text {th }}$ century Russian embryologist Alexander Kowalevsky who (amongst other studies) combined evolutionary and developmental biology to investigate the then puzzling relationship between vertebrates and invertebrates. At that time, systematic relationships within each phylum had been established, but - though Darwinian evolutionary theory predicted that vertebrate and invertebrates shared a common ancestor - clear homologies between vertebrates and invertebrates had not yet been identified. Kowalevsky investigated this problem by studying early development of amphioxus and tunicates and ultimately found embryonic homologies that united vertebrates and invertebrates.

The Kowalesky medal was established by the St. Petersberg Society of Naturalists in 1910, but the first medal was not awarded until 2001 (Mikhailov and Gilbert, 2002). The survival of this medal through a complicated and tumultuous period of Russia's scientific history is a testament to a group of dedicated Russian scientists, led by A. K. Dondua. An international committee associated with the St. Petersberg Society of Naturalists annually chooses a medal awardee.

\section{The evolution of an evolutionary developmental biolo- gist}

Michael Akam took his first degree from the Cambridge Zoology Department in 1974 with first class honors. He pursued a PhD in David Robert's laboratory at Oxford University studying larval serum proteins in Drosophila melanogaster. Michael had an interest in natural history and development since a young age and he was hoping to study the genetics and development of animal form for his PhD. He did study genetics and development during his PhD (Akam et al., 1978), but larval serum proteins did not provide him with the kind of insights into animal form that he sought. In 1978, Ed Lewis published his celebrated genetic analysis of the bithoraxcomplex. It was obvious to some people, including Michael, that cloning the Hox genes would provide critical insights into development. He therefore left Cambridge in 1979 for a post-doc in David Hogness' lab at Stanford University. Working with others in the Hogness lab he co-authored a now classic paper published in Science in 1983 describing cloning of the bithorax complex of Drosophila melanogaster(Bender et al., 1983).

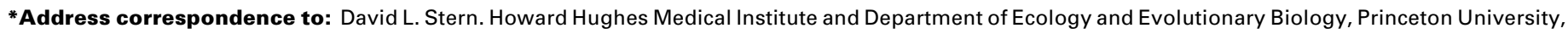
Princeton, NJ, USA Fax: +1-609-258-7138. e-mail: dstern@princeton.edu - web: www.princeton.edu/ dstern/
}

ISSN: Online 1696-3547, Print 0214-6282 


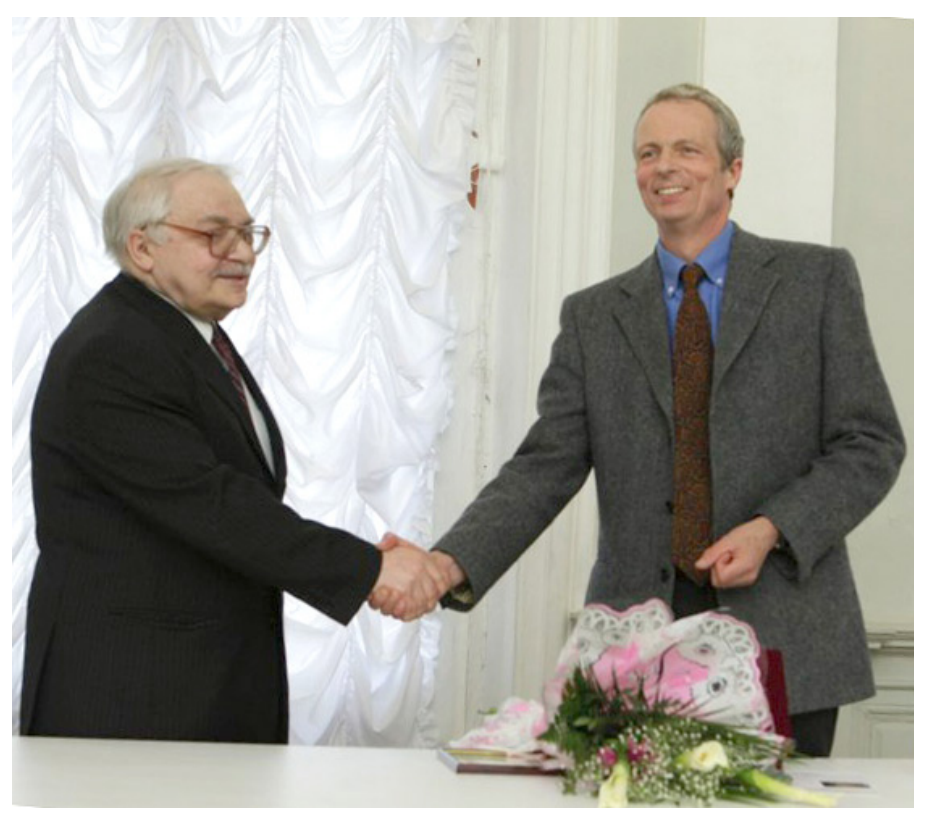

Fig. 1. Michael (right) being awarded the Kowalevsky medal in 2008. A. K. Dondua is shown on the left.

After returning to Cambridge, Michael shared a lab with Michael Ashburner's group in the Department of Genetics. According to Michael Ashburner, this was a fun and productive time for both groups. Since the 1980's Michael has published an extensive series of important papers on the developmental genetics of the Hox genes and of other genes playing important roles during development (Castelli-Gair and Akam, 1995; Castelli-Gair et al., 1994; Greig and Akam, 1993; Greig and Akam, 1995; Irish et al., 1989a; Irish et al., 1989b; Roch and Akam, 2000; Rozowski and Akam, 2002; Struhl and Akam, 1985). Michael is particularly well known for his elegant studies of the embryonic expression patterns of genes of the bithorax complex (Fig. 2). This technically demanding work demonstrated a beautiful correspondence between the expression patterns of these homeotic genes and the anatomical domains altered in the corresponding homeotic mutants (Akam, 1983; Akam and Martinez-Arias, 1985; Akam et al., 1985; Irish et al., 1989b; Martinez-Arias etal., 1987; Sanchez-Herrero and Akam, 1989).

During the late 1980's Michael was asked to become a founding member of the Wellcome-CRC Institute in Cambridge, UK (now called the Gurdon Institute). He was intimately involved in the design of the open lab spaces, which contributed to making the Institute such an exciting environment. By this time, it was clear that orthologous Hox genes and other genes involved in the regulation of development were found in distantly related organisms (Akam, 1989; Kassis et al., 1986; McGinnis etal., 1984). It became apparent that highly divergent organisms that look very different use many of the same molecular mechanisms during development. Michael quickly recognized that these facts provided the opportunity to study how molecular mechanisms had evolved to generate biological diversity (Akam, 1987a; Akam, 1989). Starting in 1990, his lab has published a series of papers documenting the expression patterns of Hox genes in insects distantly related to flies, and in crustaceans (Fig. 3) (Akam et al., 1994a; Averof and Akam, 1993; Averof and Akam, 1995a, Dawes et al., 1994; de Rosa et al., 1999; Falciani et al., 1996; Kelsh et al., 1993; Kelsh et al., 1994; Tear et al., 1990). Most of this work was performed in the pre-genome era and genomes are still unavailable for all of Michael's favorite non-Drosophilid beasts. This work was therefore time-consuming, often requiring multiple rounds of degenerate PCR, extensive screening of clones, and development of new protocols for in situ hybridization and antibody staining.

This work demonstrated that increasing complexity of the arthropod body plan did not correlate directly with the origin of new Hox genes, as had been predicted earlier. Rather, results from Michael's lab highlighted the importance of precise spatial and temporal control of Hox gene expression both in D. melanogaster development (Castelli-Gair and Akam, 1995) and as a powerful mode of evolutionary change (Averof and Akam, 1995a, Stern, 1998). While Michael recognized the potential importance of regulatory evolution early on, Michael's lab also revealed that the composition of the Hox complex has evolved (Akam et al., 1994a; Cook et al., 2004; Dawes et al., 1994; de Rosa etal., 1999; Ferrier and Akam, 1996; Falciani et al., 1996). Furthermore, his lab's analysis of Hox gene sequence divergence has also contributed to the clarification of invertebrate
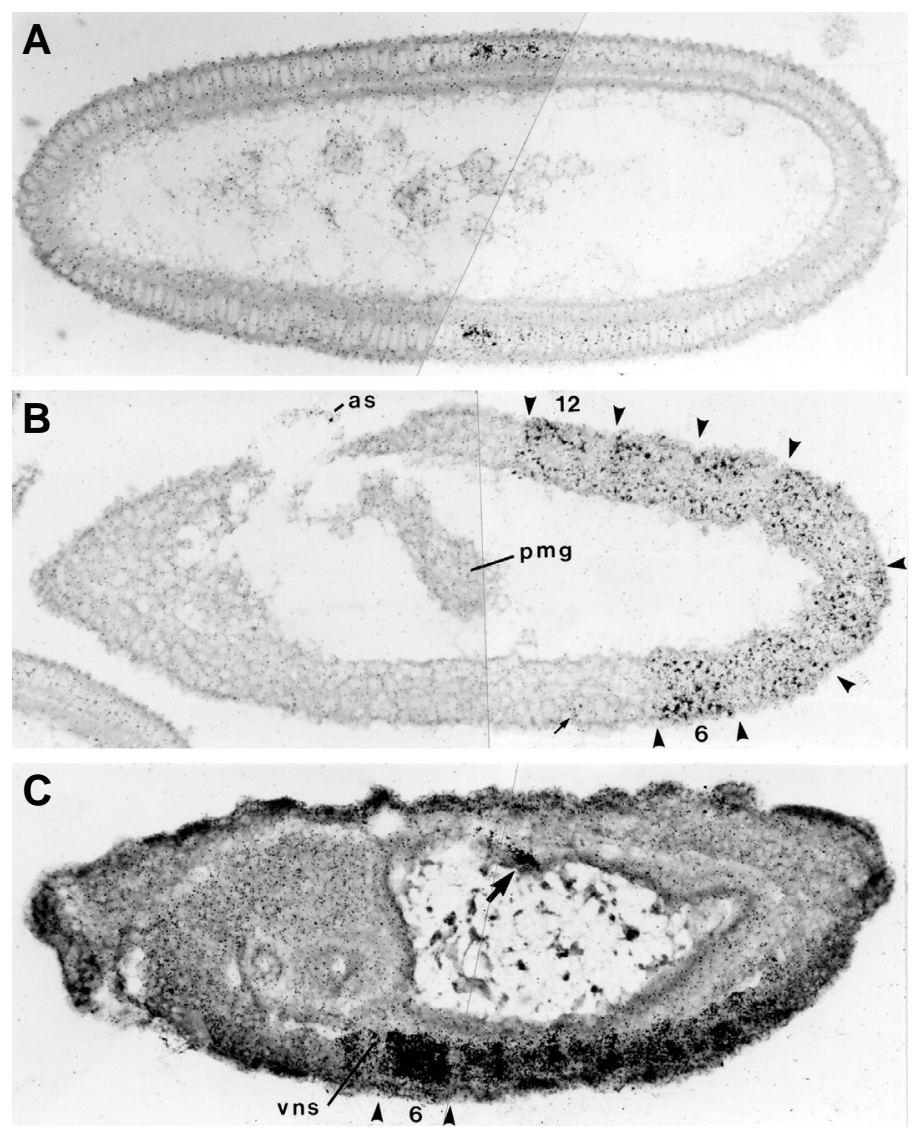

Fig. 2. Photo of of the Ultrabithorax transcript in situ in three embryonic stages of Drosophila melanogaster, from (Akam et al., 1985). (A) Cellular blastoderm stage. (B) Extended germ band stage. (C) 12-14 h embryo. 
phylogenetic relationships (Cook et al., 2004; Cook et al., 2001; Cook et al., 2005; de Rosa et al., 1999). These fundamental insights helped lay the foundation for our modern understanding of the evolution of development.

In 1994, Michael, together with Peter Holland, Phil Ingham and Greg Wray, organized the first scientific meeting focused on discussing the new data emerging from the nascent field of evolutionary developmental biology. The meeting, held during a moist and frigid Edinburgh spring - the first author's first exposure to the data from this field, as well as to the soggy Scottish climate - revealed that developmental biologists were rapidly generating an abundance of new data about the evolution of developmental mechanisms. Homologous genes were being discovered left and right, photographs of expression patterns in curious embryos abounded. Michael and his coorganizers somehow organized this menagerie into the first important edited volume covering modern evolutionary developmental biology (Akam et al., 1994b). Both the Preface, with its glance back to the late 19th century, and the chapter authored by Michael and his lab on the evolving role of Hox genes still make for informative reading (Akam et al., 1994a).

In the mid 1990's Michael applied to be the Director of the Cambridge Museum of Zoology. This was a remarkable decision since Michael was already ensconced in an exciting scientific institution - the Wellcome-CRC Institute. In addition, Michael understood that accepting the directorship meant investing a huge amount of time in fund raising to upgrade the Museum facilities. But Michael also saw the exciting opportunities this move would allow. He proceeded both to upgrade the Museum facilities, but also to turn the associated lab spaces into a powerful microcosm for the study of evolutionary developmental biology. He attracted Pat Simpson to join the museum with a lab space just upstairs from his. He also split off a portion of his lab space to be used as a young-investigator incubator. Michael has invited a series of senior postdoctoral fellows to work in this lab space as semi-independent researchers. This model has proven extremely successful, and each of his younginvestigator protégés has gone on to set up successful independent labs (in chronological order, David Stern now at Princeton University, Max Telford now at University College, London, Cassandra Extavour now at Harvard University, and Claudio Alonso, now at Sussex University). This design of the laboratory space was entirely Michael's invention and attests to his unique ability to take existing opportunities and transform them into something more than was originally intended.

The Directorship of the Museum of Zoology allows Michael both to pursue his research and to exercise his long-held devotion to public science education. In addition, he has actively sought out collaborators in a wide diversity of fields, not least his highly successful collaboration with the late Tatiana Andreeva on studies of Hox genes in Nereis (Kulakova et al., 2007). Michael has continued to promote the growth of evolutionary developmental biology in Europe by co-founding the consortium of labs known as Zoonet (www.zoonet.eu.com).

In recent years, Michael has garnered many honors for his scientific accomplishments. Michael was elected a Fellow of the Linnean Society in 1999 and a Fellow of the Royal Society in 2000. In 2005 he received the Waddington Medal of the British Society for Developmental Biology and in 2006 he was

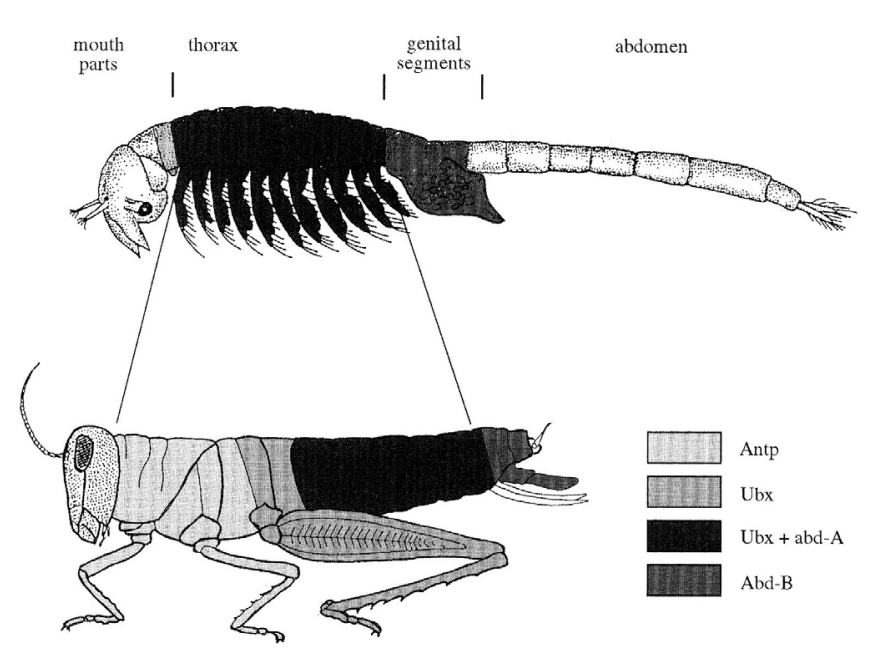

Fig. 3. Model of the evolution of Hox gene expression patterns between crustaceans and insects, from (Akam, 1995). This model illustrates that the traditionally defined thorax of crustacea may be homologous to the entire pre-genital trunk of insects. Gene abbreviations: Antp, Antennapedia, Ubx, Ultrabithorax, abd-A, abdominal-A, Abd$B$, Abdominal-B.

elected a fellow of the American Association for the Advancement of Science.

\section{The three tributaries of Michael Akam's contribution to evolutionary developmental biology}

As we re-read some of Michael's papers in preparation for writing this article, we detected three noteworthy trends in his curriculum vitae. First, Michael has made major contributions to our understanding of Drosophila melanogaster developmental biology. This experience gave him the foundational knowledge and expertise to launch successful comparative investigations. Second, Michael has maintained a steady focus on a few key problems in evolutionary developmental biology. Early on, he focused on the evolving role of Hox genes in animal evolution. More recently, his lab has focused on the evolution of segmentation mechanisms (Chipman and Akam, 2008; Chipman et al., 2004a; Chipman et al., 2004b; Dearden and Akam, 2000; Peel and Akam, 2003; Peel et al., 2005; Peel et al., 2006). This focus has yielded many fruit. Finally, Michael has written several influential synthetic reviews. His earliest, and one for which he is justifiably proud, is a 1987 review on the mechanisms of segmentation in Drosophila (Akam, 1987b). During the 1990's Michael wrote a series of synthetic reviews that brought together the two empirical streams active in his lab into a coherent model of Hox gene evolution (Akam, 1995; Akam, 1998; Akam et al., 1994a; Averof and Akam, 1995b). These reviews are extraordinarily insightful, without being flashy and without introducing new jargon (for which we are ever so grateful).

\section{Michael the Mentor}

One of Michael's most important contributions to science and one that is not overtly reflected in his estimable $\mathrm{CV}$ - is his 
passion for, and approach to, mentoring. We asked some of our colleagues who passed through Michael's laboratory over the past 20 years to share their thoughts with us on Michael's mentorship style. Their responses are consistent with the authors' experiences. Several themes shone through our colleagues' comments and we now feel confident that they reflect Michael's consistent approach to mentoring.

Michael possesses the healthiest kind of self confidence: a confidence that allows pursuit of scientific answers for their own sake rather than for any personal gain or fame and a confidence that allows for a selfless and genuine support of others. Overall, this combination of intellectual rigor with a genuine concern for, and support of, others is one of Michael's most admirable qualities. Michael has an incredibly high threshold for satisfactory science. He does not impress easily, but once he is satisfied of the fundamental truth of an observation, he combines the observations together with his profound understanding of developmental and comparative biology and always - truly always - comes back with a deeply interesting and insightful question. This is the quality that has most impressed itself upon many we have talked with. More quickly than most, Michael absorbs facts and asks questions that motivate both deeper thought and good experiments.

Michael has a piercing intellect and his exacting standards might lead one to expect a somewhat stern and distant scientist. However, this could not be further from the truth. Michael is patient and never prescriptive. Many a graduate student looks back on their thesis writing in Michael's lab with considerable awe at the patience they later realized must have been involved. Rob Kelsh writes: "His mentoring is certainly sacrificial - I recall vividly that when I was writing up, at least two sessions when we discussed my chapters involved me going to see him at home because he was recovering from pneumonia. He was always surprisingly patient. He was very much ready for us to learn for ourselves, with just gentle guidance, mostly only when requested. (Although I think we never had any doubt when Michael thought what we were saying was stupid, just from the look on his face and the accompanying silence!)".

Whilst it is known that students learn best by "discovering it for themselves," few researchers have quite Michael's level of patience for letting students always learn that way! But students and postdocs are not simply set adrift in Michael's lab. Michael is skilled at coupling investigative freedom with sufficient guidance to maintain momentum on a project. Michael is also very approachable for advice. Although it can be daunting to receive such razor sharp wisdom, this is outweighed by the fact that his advice is clear, considered, individualized and highly valuable. Michael takes this aspect of mentorship very seriously and invests the time needed to consider the specifics of every situation. In the words of a former lab member: "In all cases I would say his advice has been very perceptive, both of the situation and of me." This was a common sentiment.

These attributes are also part of Michael's success in supporting young scientists as they launch their own independent careers. Max Telford writes: "It was a real pleasure to be there, because Michael managed to step back and allow one to feel completely independent while at the same time being available in the next door office for sage advice and discussion of anything from science to job and grant applications."
Michael also has a very strong commitment to family. He is dedicated to his family and proud of their accomplishments. Talk of his family is a natural and enjoyable part of interacting with Michael. When his children were younger, Michael would structure his work to maximize time with his family wherever possible. He brought manuscripts, thesis drafts and journal articles home to work on later in the evening and held the occasional student advising session at his house. Students, postdocs and colleagues have all enjoyed spending time with Michael's family (from working in the garden to helping with birthday parties!). The pot-luck suppers held at his house are particularly memorable. As David Ferrier recalls "Pot-luck suppers are an abiding memory; a wide range of food, enhanced by the multi-national nature of the research group, which always seemed to mesh well. But you always knew that you'd have to work for your bread once the scientific discussion started, which was the real purpose of the evening. It was a superb environment in which a fresh-faced graduate student could learn how to really think about science."

Michael's family commitment also translates into a genuine understanding of that same commitment in others. He enjoys getting to know the families of those he works with. On a recent visit he completely enamored $\mathrm{RH}$ 's four-year old daughter with his descriptions of fossil hunting and his promise of a guided tour of the museum when we next return to Cambridge. His commitment to getting to know "the whole person", in turn, is part of what makes Michael's advising so valuable.

\section{In conclusion}

Michael likes to recount how the start to his undergraduate training in biology at Cambridge involved the disassembly and reassembly of a microscope. He thinks this is a great way to get started in biology. If we may be forgiven some armchair psychology, we think this anecdote reveals a lot about Michael. He is always keen to understand the inner workings of natural phenomena, and he uses this mechanistic knowledge to generate insights about the whole. This approach to science is revealed by his thorough analyses of Hox gene function combined with his comparative studies of the evolution of form. Michael continues to lead an active research laboratory that is currently focused on understanding the evolution of segmentation mechanisms in the animals. We can look forward to his lab providing further deep insights into the evolution of development in coming years.

\section{Acknowledgements}

We would like to thank David Ferrier, Robert Kelsh, Max Telford and Michael Ashburner for sharing their thoughts and memories of working with Michael, and for their comments on this manuscript.

\section{References}

AKAM, M. (1987a). Insect evolution. Molecules and morphology. Nature 327: 184185.

AKAM, M. (1987b). The molecular basis for metameric pattern in the Drosophila embryo. Development 101: 1-22.

AKAM, M. (1989). Hox and HOM: homologous gene clusters in insects and vertebrates. Cel/57: 347-349.

AKAM, M. (1995). Hox genes and the evolution of diverse body plans. Philos Trans $R$ Soc Lond B Biol Sci349: 313-319.

AKAM, M. (1998). Hox genes, homeosis and the evolution of segment identity: no 
need for hopeless monsters. Int J Dev Bio/42: 445-451.

AKAM, M., AVEROF, M., CASTELLI-GAIR, J., DAWES, R., FALCIANI, F. and FERRIER, D. (1994a). The evolving role of Hox genes in arthropods. Dev Supp/ 209-215.

AKAM, M., HOLLAND, P., INGHAM, P. and WRAY, G. (1994b). The evolution of developmental mechanisms. Cambridge: Company of Biologists.

AKAM, M.E. (1983). The location of Ultrabithorax transcripts in Drosophila tissue sections. EMBO J2: 2075-2084.

AKAM, M.E. and MARTINEZ-ARIAS, A. (1985). The distribution of Ultrabithorax transcripts in Drosophila embryos. EMBO J4: 1689-1700.

AKAM, M.E., MARTINEZ-ARIAS, A., WEINZIERL, R. and WILDE, C.D. (1985). Function and expression of ultrabithorax in the Drosophila embryo. Cold Spring Harb Symp Quant Bio/50: 195-200.

AKAM, M.E., ROBERTS, D.B., RICHARDS, G.P. and ASHBURNER, M. (1978). Drosophila: the genetics of two major larval proteins. Cel/13: 215-225.

AVEROF, M. and AKAM, M. (1993). HOM/Hox genes of Artemia: implications for the origin of insect and crustacean body plans. Curr Bio/3: 73-78.

AVEROF, M. and AKAM, M. (1995a). Hox genes and the diversification of insect and crustacean body plans. Nature 376: 420-423.

AVEROF, M. and AKAM, M. (1995b). Insect-crustacean relationships: insights from comparative developmental and molecular studies. Phil. Trans. Royal Soc. 347: 293-303.

BENDER, W., AKAM, M., KARCH, F., BEACHY, P.A., PEIFER, M., SPIERER, P., LEWIS, E.B. and HOGNESS, D.S. (1983). Molecular Genetics of the Bithorax Complex in Drosophila melanogaster. Science 221: 23-29.

CASTELLI-GAIR, J. and AKAM, M. (1995). How the Hox gene Ultrabithorax specifies two different segments: the significance of spatial and temporal regulation within metameres. Development 121: 2973-2982.

CASTELLI-GAIR, J., GREIG, S., MICKLEM, G. and AKAM, M. (1994). Dissecting the temporal requirements for homeotic gene function. Development 120: 198395.

CHIPMAN, A.D. and AKAM, M. (2008). The segmentation cascade in the centipede Strigamia maritima: involvement of the Notch pathway and pair-rule gene homologues. Dev Bio/319: 160-169.

CHIPMAN, A.D., ARTHUR, W. and AKAM, M. (2004a). A double segment periodicity underlies segment generation in centipede development. Curr Biol 14: 1250-1255.

CHIPMAN, A.D., ARTHUR, W. and AKAM, M. (2004b). Early development and segment formation in the centipede, Strigamia maritima (Geophilomorpha). Evol Dev6: 78-89.

COOK, C.E., JIMENEZ, E., AKAM, M. and SALO, E. (2004). The Hox gene complement of acoel flatworms, a basal bilaterian clade. Evol Dev6: 154-163.

COOK, C.E., SMITH, M.L., TELFORD, M.J., BASTIANELLO, A. and AKAM, M. (2001). Hox genes and the phylogeny of the arthropods. Curr Bio/11: 759-763.

COOK, C.E., YUE, Q. and AKAM, M. (2005). Mitochondrial genomes suggest that hexapods and crustaceans are mutually paraphyletic. Proc Biol Sci272: 12951304.

DAWES, R., DAWSON, I., FALCIANI, F., TEAR, G. and AKAM, M. (1994). Dax, a locust Hox gene related to fushi-tarazu but showing no pair-rule expression. Development 120: 1561-1572.

DE ROSA, R., GRENIER, J.K., ANDREeVA, T., COOK, C.E., ADOUTTE, A., AKAM, M., CARROLL, S.B. and BALAVOINE, G. (1999). Hox genes in brachiopods and priapulids and protostome evolution. Nature 399: 772-776.

DEARDEN, P. and AKAM, M. (2000). A role for Fringe in segment morphogenesis but not segment formation in the grasshopper, Schistocerca gregaria. Dev Genes Evo/210: 329-336.

FALCIANI, F., HAUSDORF, B., SCHRODER, R., AKAM, M., TAUTZ, D., DENELL,
R. and BROWN, S. (1996). Class 3 Hox genes in insects and the origin of zen. Proc Natl Acad Sci USA 93: 8479-8484.

FERRIER, D.E. and AKAM, M. (1996). Organization of the Hox gene cluster in the grasshopper, Schistocerca gregaria. ProcNat/Acad Sci USA 93: 13024-13029.

GREIG, S. and AKAM, M. (1993). Homeotic genes autonomously specify one aspect of pattern in the Drosophila mesoderm. Nature 362: 630-632.

GREIG, S. and AKAM, M. (1995). The role of homeotic genes in the specification of the Drosophila gonad. Curr Bio/5: 1057-1062.

IRISH, V., LEHMANN, R. and AKAM, M. (1989a). The Drosophila posterior-group gene nanos functions by repressing hunchback activity. Nature 338: 646-648.

IRISH, V.F., MARTINEZ-ARIAS, A. and AKAM, M. (1989b). Spatial regulation of the Antennapedia and Ultrabithorax homeotic genes during Drosophila early development. EMBO J8: 1527-1537.

KASSIS, J.A., POOLE, S.J., WRIGHT, D.K. and O'FARRELL, P.H. (1986). Sequence conservation in the protein coding and intron regions of the engrailed transcription unit. The EMBO Journa/5: 3583-3589.

KELSH, R., DAWSON, I. and AKAM, M. (1993). An analysis of abdominal-B expression in the locust Schistocerca gregaria. Development 117: 293-305.

KELSH, R., WEINZIERL, R.O., WHITE, R.A. and AKAM, M. (1994). Homeotic gene expression in the locust Schistocerca: an antibody that detects conserved epitopes in Ultrabithorax and abdominal-A proteins. Dev Genet 15: 19-31.

KULAKOVA, M., BAKALENKO, N., NOVIKOVA, E., COOK, C.E., ELISEEVA, E., STEINMETZ, P.R., KOSTYUCHENKO, R.P., DONDUA, A., ARENDT, D., AKAM, M. et al. (2007). Hox gene expression in larval development of the polychaetes Nereis virens and Platynereis dumerilii (Annelida, Lophotrochozoa). Dev Genes Evo/217: 39-54.

MARTINEZ-ARIAS, A., INGHAM, P.W., SCOTT, M.P. and AKAM, M.E. (1987). The spatial and temporal deployment of Dfd and Scr transcripts throughout development of Drosophila. Development 100: 673-683.

MCGINNIS, W., GARBER, R.L., WIRZ, J., KUROIWA, A. and GEHRING, W.J. (1984). A homologous protein-coding sequence in Drosophila homeotic genes and its conservation in other metazoans. Cel/37: 403-408.

MIKHAILOV, A.T. and GILBERT, S.F. (2002). From development to evolution: the re-establishment of the «Alexander Kowalevsky Medal». Int J Dev Bio/46: 693698.

PEEL, A. and AKAM, M. (2003). Evolution of segmentation: rolling back the clock. Curr Bio/13: R708-R710.

PEEL, A.D., CHIPMAN, A.D. and AKAM, M. (2005). Arthropod segmentation: beyond the Drosophila paradigm. Nat Rev Genet 6: 905-916.

PEEL, A.D., TELFORD, M.J. and AKAM, M. (2006). The evolution of hexapod engrailed-family genes: evidence for conservation and concerted evolution. Proc Biol Sci273: 1733-1742.

ROCH, F. and AKAM, M. (2000). Ultrabithorax and the control of cell morphology in Drosophila halteres. Development 127: 97-107.

ROZOWSKI, M. and AKAM, M. (2002). Hox gene control of segment-specific bristle patterns in Drosophila. Genes Dev 16: 1150-1162.

SANCHEZ-HERRERO, E. and AKAM, M. (1989). Spatially ordered transcription of regulatory DNA in the bithorax complex of Drosophila. Development 107: 321329.

STERN, D.L. (1998). A role of Ultrabithorax in morphological differences between Drosophila species. Nature 396: 463-466.

STRUHL, G. and AKAM, M. (1985). Altered distributions of Ultrabithorax transcripts in extra sex combs mutant embryos of Drosophila. EMBO J4: 3259-3264.

TEAR, G., AKAM, M. and MARTINEZ-ARIAS, A. (1990). Isolation of an abdominalA gene from the locust Schistocerca gregaria and its expression during early embryogenesis. Development 110: 915-925. 


\section{Further Related Reading, published previously in the Int. J. Dev. Biol.}

See Special Issue Pattern Formation edited by Michael K. Richardson and Cheng-Ming Chuong at:

http://www.ijdb.ehu.es/web/contents.php?vol=53\&issue =5-6

Peter Holland, homeobox genes and the developmental basis of animal diversity Sebastian M. Shimeld

Int. J. Dev. Biol. (2008) 52: 3-7

Evolutionary embryology resurrected in Japan with a new molecular basis: Nori Satoh and the history of ascidian studies originating in Kyoto during the 20th century

Shigeru Kuratani, Hiroshi Wada, Rie Kusakabe And Kiyokazu Agata

Int. J. Dev. Biol. (2006) 50: 451-454

Putting evo-devo into focus. An interview with Scott F. Gilbert

Alexander T. Mikhailov

Int. J. Dev. Biol. (2005) 49: 9-16

From development to evolution: the re-establishment of the "Alexander Kowalevsky Medal»

Alexander T Mikhailov and Scott F Gilbert

Int. J. Dev. Biol. (2002) 46: 693-698

Evolution of the Hox/ParaHox gene clusters

David E K Ferrier and Carolina Minguillón

Int. J. Dev. Biol. (2003) 47: 605-611

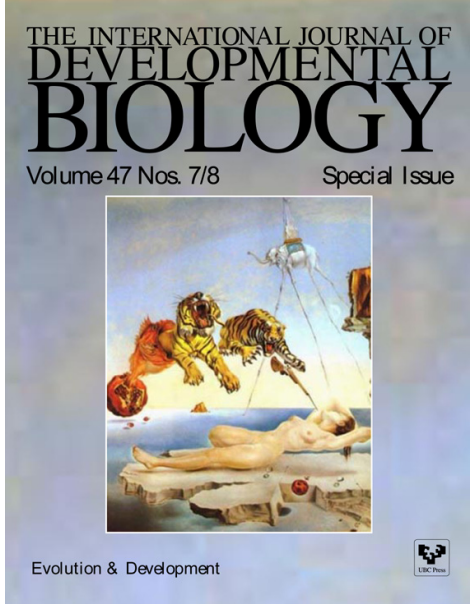

5 yr ISI Impact Factor $(2008)=3.271$

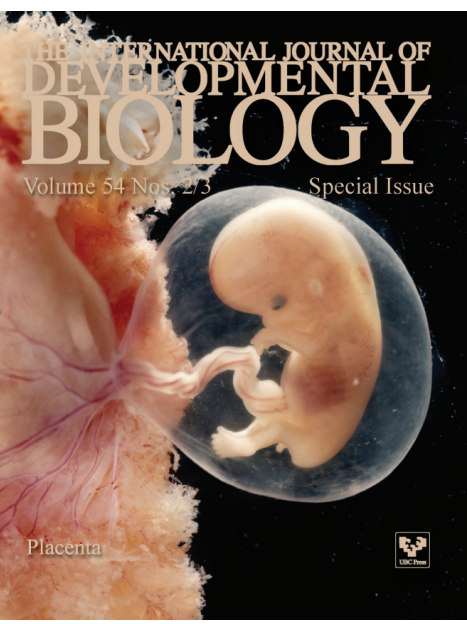

